\title{
Lung Spindle Cell Carcinoma
}

National Cancer Institute

\section{Source}

National Cancer Institute. Lung Spindle Cell Carcinoma. NCI Thesaurus. Code C45541.

A morphologic variant of sarcomatoid carcinoma characterized by the presence of malignant spindle cells and focal lymphoplasmacytic infiltrates. Adenocarcinoma cells, malignant squamous cells, and giant cells are not present. 